\title{
DOES SUBSTRATE QUALITY INFLUENCE DIVERSITY AND HABITAT USE OF WATERBIRDS?: A CASE STUDY FROM WETLANDS IN SOUTHERN INDIA
}

\author{
V. K. BOBIKA $\otimes^{1}$, MOHAMED DHAYA EL-HAK KHEMIS ${ }^{2}$, R. RENILA ${ }^{1}$, K. MANJUSHA ${ }^{1}$, K. M. AARIF ${ }^{3}$ \\ ${ }^{1}$ Department of Zoology, University of Calicut, PO Thenjipalam, Kerala 673635, India; e-mail: bobikavk1994@gmail.com \\ ${ }^{2}$ Department of Biology, University of Badji Mokhtar of Annaba, Annaba 23000, Algeria \\ ${ }^{3}$ Terrestrial Ecology, Centre for Environment and Water, King Fahad University of Petroleum and Minerals, Dharan 31261, Saudi Arabia \\ $\bowtie$ Corresponding author
}

Received: 24 February 2019 / Accepted: 17 May 2019

Abstract

Bobika V.K., Khemis M.D.E., Renila R., Manjusha K., Aarif K.M.: Does substrate quality influence diversity and habitat use of waterbirds?: A case study from wetlands in southern India. Ekológia (Bratislava), Vol. 40, No. 1, p. 70-79, 2021.

\begin{abstract}
Wetland acts as an important habitat that supports a massive diversity of organisms, especially waterbirds. We examined waterbird diversity and habitat use in relation to abiotic factors at Mavoor and Vazhakkad, two major wetlands in southwestern India. The study was carried out from 2015 December to 2016 November. A total of 50 species from Vazhakkad and 40 species from Mavoor wetlands were recorded; 12 species were exclusive to Vazhakkad and three to Mavoor. Among them, 16 species were winter visitors in Vazhakkad and nine in Mavoor. Highest diversity of waterbirds was observed in the agroecosystem of Vazhakkad. Physicochemical variables were recorded for the two wetlands, and their effect on waterbird richness, abundance and diversity were correlated. Multivariate analysis showed the variation in diversity between the two wetlands (MANOVA: Wilks' $\lambda=$ $0.933, F=3.69, P=0.006$ ) and habitat wetland interaction (MANOVA: Wilks' $\lambda=0.694, F=10.25, P=0.00$ ). Nonlinear regression analyses were carried out between the evolution of the ecological index in the two wetlands separately. The present study could determine the effects of anthropogenic
\end{abstract} disturbances on wetland function from this study.

Key words: richness, abundance, abiotic factors, agricultural land, Mavoor, Vazhakkad.

\section{Introduction}

Wetlands support high diversity of resident and migrant waterbirds (Amezaga et al., 2002; Pandiyan et al., 2014). They forage on small vertebrates and other benthic organisms in the wetland (Pandiyan et al., 2014), which in turn is influenced by the physical and chemical properties of the wetland (Liang et al., 2002). The influence of abiotic factors on the waterbird congregations in wetlands has long been studied by many authors (Nagarajan and Thiyagesan, 1996; Malik and Joshi, 2013). Water quality acts as an important factor to estimate the health of the wetland, since the same is responsible for the prey availability and productivity of an ecosystem (Manikannan et al., 2012). This directly or indirectly affects the distribution and habitat use of waterbirds (Manikannan et al., 2012; Elafri et al., 2017).

Tremendous anthropogenic pressures have caused rapid decline in the wetlands worldwide (Shine, Klemm, 1999), which is responsible for the catastrophic decline in waterbird populations around the world (Stroud et al., 2004; BirdLife International, 2008; Wetlands International, 2012). In India, 69\% of the area consists of inland wetlands (Bassi et al., 2014), of which many wetlands are threatened and many are already degraded (Central Pollution Control Board, 2008). To overcome this rapid loss of wetlands, it is highly essential to provide an alternate habitat to support waterbirds (Elphick, Oring, 2003), and rice fields can act as a substitute habitat for waterbirds during winter (Strum et al., 2013; Sundar, Subramanya, 2010; Acosta et al., 2010). Recent studies (Jones et al., 2009; Hamza, Selmi, 2015) have shown the role of habitat features and human presence in shaping the richness and abundance of individual waterbird species due to the changes in habitat use (Zheng et al., 2015).

Many waterbird species are declining worldwide (BirdLife International, 2017). Southern India is a globally important wintering site for waterbirds migrating along the Central Asian and South Asian Flyway, where waterbird abundance has decreased by $40 \%$ in the Pichavaram mangroves of Tamil Nadu on the east coast (Sandilyan et al., 2010) and by $44 \%$ in the Kadalundi Vallikunnu Community Reserve on the west coast (Aarif et al., 2014; 2020). In the present study, Mavoor and Vazhakkad - two wetlands in southwestern India - are considered since detailed information on the influence of water and sediment characteristics on waterbird distribution and richness is lacking in these wetlands. A checklist on the waterbirds by Aarif and Basheer (2012) and a behavioral study of cormorant (Zeenath, 2009) are the only studies conducted in Mavoor wetlands. Hence, this study evaluated the effect of abiotic factors with respect to Mavoor and Vazhakkad wetlands and the

(C) The Author(s) 2021. This is an open access article distributed under the terms of the CC BY-NC-ND license.

https://content.sciendo.com/view/journals/eko/eko-overview.xml 


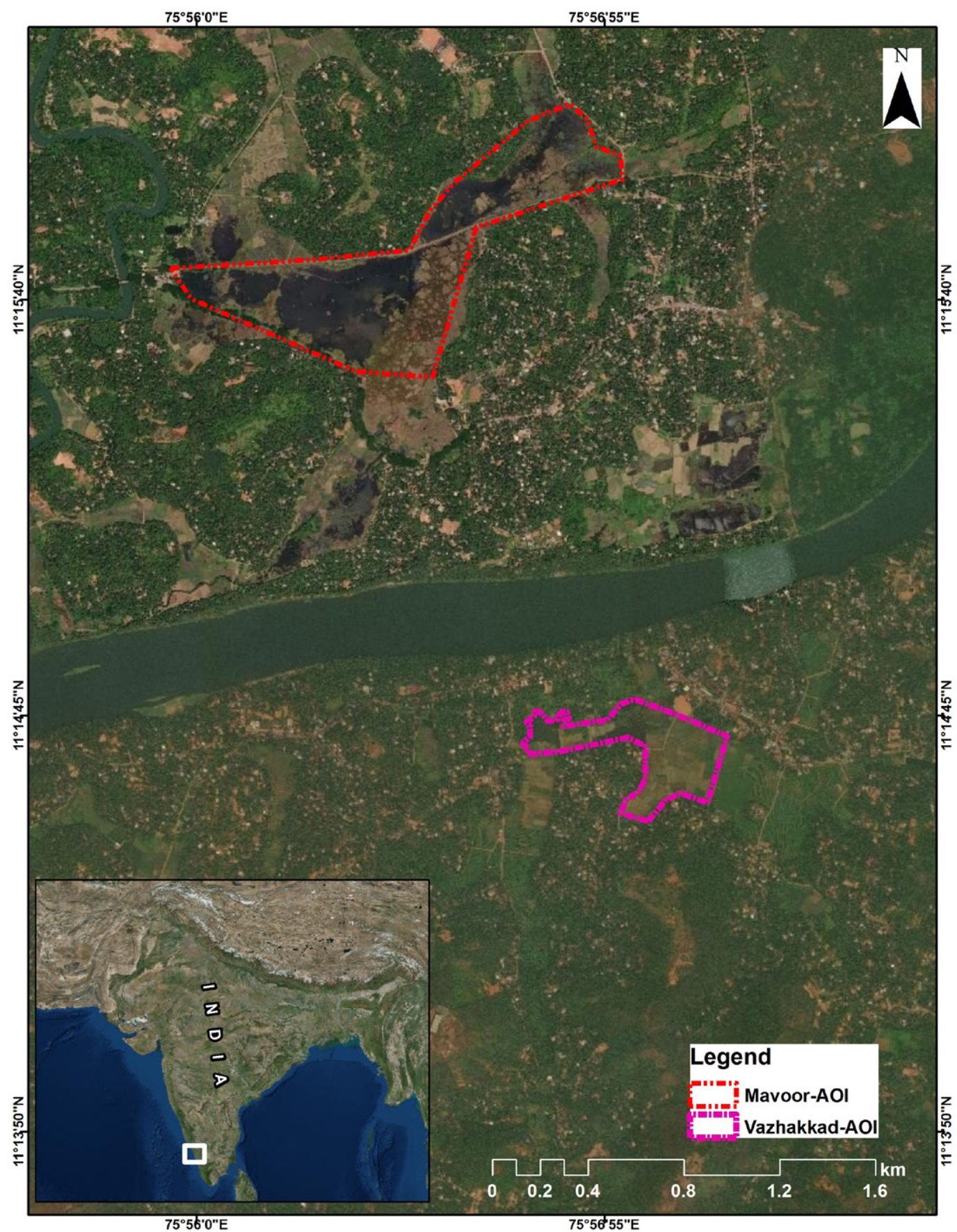

Fig. 1. Study area. Red dotted lines represent Mavoor wetlands and pink dotted lines represent Vazhakkad wetlands.

results will be valuable as baseline information for future studies. The study aims to (1) estimate the distribution and population status of waterbirds in Mavoor \& Vazhakkad wetlands and to (2) compare the two wetlands with relation to abiotic factors and habitat use of waterbirds.

\section{Material and methods}

The study was conducted from December 2015 to November 2016 at Mavoor and Vazhakkad wetlands (Fig. 1).

\section{Study area}

Both wetlands were earlier paddy fields, later modified into jheels by mining of clay. When Kavanakkallu regulator cum bridge was constructed over Chaliyar River, Mavoor and Vazhakkad fields were inundated with water. Then, water was drained and modified for agricultural and construction purposes.

Mavoor wetland is located on the northwestern side of Mavoor town on the banks of Chaliyar River in Kozhikode district. This wetland includes five interconnected sites in the Mavoor 
Table 1. List of waterbirds recorded from Vazhakkad and Mavoor wetlands with reference to migratory and abundance status.

\begin{tabular}{|c|c|c|c|c|c|}
\hline \multirow{2}{*}{ Common Name } & \multirow{2}{*}{ Scientific Name } & \multicolumn{2}{|c|}{ Abundance Status } & \multicolumn{2}{|c|}{ Migratory Status } \\
\hline & & Vazhakkad & Mavoor & Vazhakkad & Mavoor \\
\hline Brahmini Kite & Haliastur indus & Com & Com & $\mathrm{R} / \mathrm{LM}$ & $\mathrm{R} / \mathrm{LM}$ \\
\hline Pariah Kite & Milvus migrans & Com & Com & $\mathrm{R} / \mathrm{LM}$ & $\mathrm{R} / \mathrm{LM}$ \\
\hline Black Capped Kingfisher & Halcyon pileata & - & $\mathrm{Ra}$ & - & $\mathrm{M}$ \\
\hline Common Kingfisher & Alcedo atthis & Com & Com & $\mathrm{R}$ & $\mathrm{R} / \mathrm{LM}$ \\
\hline Lesser Pied Kingfisher & Ceryle rudis & Com & Com & $\mathrm{R} / \mathrm{LM}$ & $\mathrm{R} / \mathrm{LM}$ \\
\hline Stork Billed Kingfisher & Halcyon capensis & Com & Com & $\mathrm{R} / \mathrm{LM}$ & $\mathrm{R} / \mathrm{LM}$ \\
\hline White Throated Kingfisher & Halcyon smyrnensis & Com & Com & R/LM & $\mathrm{R} / \mathrm{LM}$ \\
\hline Cotton Pygmy Goose & Nettapus coromandelianus & Com & Com & $\mathrm{R} / \mathrm{LM}$ & $\mathrm{R} / \mathrm{LM}$ \\
\hline Lesser Whistling Duck & Dendrocygna javanica & Com & Com & $\mathrm{R} / \mathrm{LM}$ & $\mathrm{R} / \mathrm{LM}$ \\
\hline Gadwall & Anas strepera & Uncom & Uncom & $\mathrm{M}$ & $\mathrm{M}$ \\
\hline Gargeny & Anas querquedula & Uncom & Uncom & $\mathrm{M}$ & M \\
\hline Northern Pintail & Anas acuta & $\mathrm{Ra}$ & $\mathrm{Ra}$ & $\mathrm{M}$ & M \\
\hline Oriental Darter & Anhinga melanogaster & Com & Com & R/LM & $\mathrm{R}$ \\
\hline Black Bittern & Dupetor flavicollis & Uncom & Uncom & $\mathrm{R} / \mathrm{LM}$ & $\mathrm{R} / \mathrm{LM}$ \\
\hline Black Crowned Night Heron & Nycticorax nycticorax & Uncom & Uncom & $\mathrm{R}$ & $\mathrm{R} / \mathrm{LM}$ \\
\hline Cattle Egret & Bubulcus ibis & Com & Com & $\mathrm{R} / \mathrm{LM}$ & $\mathrm{R} / \mathrm{LM}$ \\
\hline Large Egret & Casmero diusalbus & Uncom & Uncom & $\mathrm{R} / \mathrm{LM}$ & $\mathrm{R} / \mathrm{LM}$ \\
\hline Grey Heron & Ardea cinerea & Com & - & $\mathrm{R} / \mathrm{LM}$ & - \\
\hline Little Egret & Egretta garzetta & Com & Com & $\mathrm{R} / \mathrm{LM}$ & $\mathrm{R} / \mathrm{LM}$ \\
\hline Little Green Heron & Butorides striata & Uncom & - & $\mathrm{R} / \mathrm{LM}$ & - \\
\hline Median Egret & Mesophoyx intermedia & Com & Com & $\mathrm{R} / \mathrm{LM}$ & $\mathrm{R} / \mathrm{LM}$ \\
\hline Pond Heron & Ardeola grayii & Com & Com & $\mathrm{R} / \mathrm{LM}$ & $\mathrm{R} / \mathrm{LM}$ \\
\hline Purple Heron & Ardea purpurea & Com & Com & $\mathrm{R} / \mathrm{LM}$ & $\mathrm{R}$ \\
\hline Yellow Bittern & Ixobrychus sinensis & Uncom & - & $\mathrm{R} / \mathrm{LM}$ & - \\
\hline Grey Plover & Pluvialis squatarola & Com & - & $\mathrm{M}$ & - \\
\hline Little Ringed Plover & Charadrius bubius & Uncom & Uncom & R/LM & $\mathrm{R} / \mathrm{LM}$ \\
\hline Pacific Golden Plover & Pluvialis fulva & Uncom & - & $\mathrm{M}$ & - \\
\hline Red Wattled Lapwing & Vanellus indicus & Com & Com & $\mathrm{R} / \mathrm{LM}$ & $\mathrm{R} / \mathrm{LM}$ \\
\hline Yellow Wattled Lapwing & Vanellus malabaricus & Com & - & $\mathrm{R} / \mathrm{LM}$ & - \\
\hline Black Winged Stilt & Himantopus himantopus & Uncom & - & $\mathrm{M}$ & - \\
\hline Asian Openbill Stork & Anastomus oscitans & Uncom & Uncom & $\mathrm{R} / \mathrm{LM}$ & $\mathrm{R} / \mathrm{LM}$ \\
\hline White necked Stork & Metopidius indicus & $\mathrm{Ra}$ & $\mathrm{Ra}$ & R/LM & $\mathrm{R} / \mathrm{LM}$ \\
\hline Bronze Winged Jacana & Metopidius indicus & Com & Com & $\mathrm{R} / \mathrm{LM}$ & $\mathrm{R}$ \\
\hline Pheasant Tailed Jacana & Hydrophasianus chirurgus & - & $\mathrm{Ra}$ & - & $\mathrm{R} / \mathrm{LM}$ \\
\hline Lesser Crested Terns & Sterna bengalensis & $\mathrm{Ra}$ & $\mathrm{Ra}$ & $\mathrm{M}$ & $\mathrm{M}$ \\
\hline River Tern & Sterna aurantia & $\mathrm{Ra}$ & - & $\mathrm{R} / \mathrm{LM}$ & - \\
\hline Whiskered Tern & Chlidonias hybridus & Com & Com & $\mathrm{R} / \mathrm{LM}$ & $\mathrm{R} / \mathrm{LM}$ \\
\hline Indian Shag & Phalacrocorax fuscicollis & Uncom & Com & $\mathrm{R} / \mathrm{LM}$ & $\mathrm{R} / \mathrm{LM}$ \\
\hline Little Cormorant & Phalacrocorax niger & Com & Com & $\mathrm{R} / \mathrm{LM}$ & $\mathrm{R} / \mathrm{LM}$ \\
\hline Common Coot & Fulica atra & - & Uncom & - & $\mathrm{M}$ \\
\hline Purple Moorhen & Porphyrio porphyrio & Com & Com & $\mathrm{R} / \mathrm{LM}$ & $\mathrm{R} / \mathrm{LM}$ \\
\hline Ruddy Breasted Crake & Porzana fusca & Uncom & - & $\mathrm{R} / \mathrm{LM}$ & - \\
\hline Watercock & Gallicrex cinerea & Com & Com & $\mathrm{R} / \mathrm{LM}$ & $\mathrm{R}$ \\
\hline White Breasted Waterhen & Amaurornis phoenicurus & Com & Com & $\mathrm{R} / \mathrm{LM}$ & $\mathrm{R} / \mathrm{LM}$ \\
\hline Common Sandpiper & Actitis hypoleucos & Uncom & Uncom & $\mathrm{R} / \mathrm{LM}$ & $\mathrm{R} / \mathrm{LM}$ \\
\hline Green Sandpiper & Tringa ochropus & $\mathrm{Ra}$ & - & $\mathrm{M}$ & - \\
\hline Common Greenshank & Tringa nebularia & $\mathrm{Ra}$ & - & $\mathrm{M}$ & - \\
\hline Marsh Sandpiper & Tringa stagnatilis & Uncom & Uncom & $\mathrm{M}$ & $\mathrm{M}$ \\
\hline Wood Sandpiper & Tringa glareola & Uncom & Uncom & $\mathrm{M}$ & $\mathrm{M}$ \\
\hline Common Snipe & Gallinago gallinago & Com & - & $\mathrm{M}$ & - \\
\hline Greater Painted Snipe & Rostratula benghalensis & $\mathrm{Ra}$ & Uncom & $\mathrm{R} / \mathrm{LM}$ & $\mathrm{R} / \mathrm{LM}$ \\
\hline Oriental White Ibis & Threskiornis melanocephalus & Com & Com & $\mathrm{R} / \mathrm{LM}$ & $\mathrm{R} / \mathrm{LM}$ \\
\hline Glossy Ibis & Plegadis falcinellus & $\mathrm{Ra}$ & - & $\mathrm{M}$ & - \\
\hline
\end{tabular}

Notes: ${ }^{\star}$ Com - common; Uncom - uncommon; Ra - rare; M - migrant; LM - local movement; R -resident. 


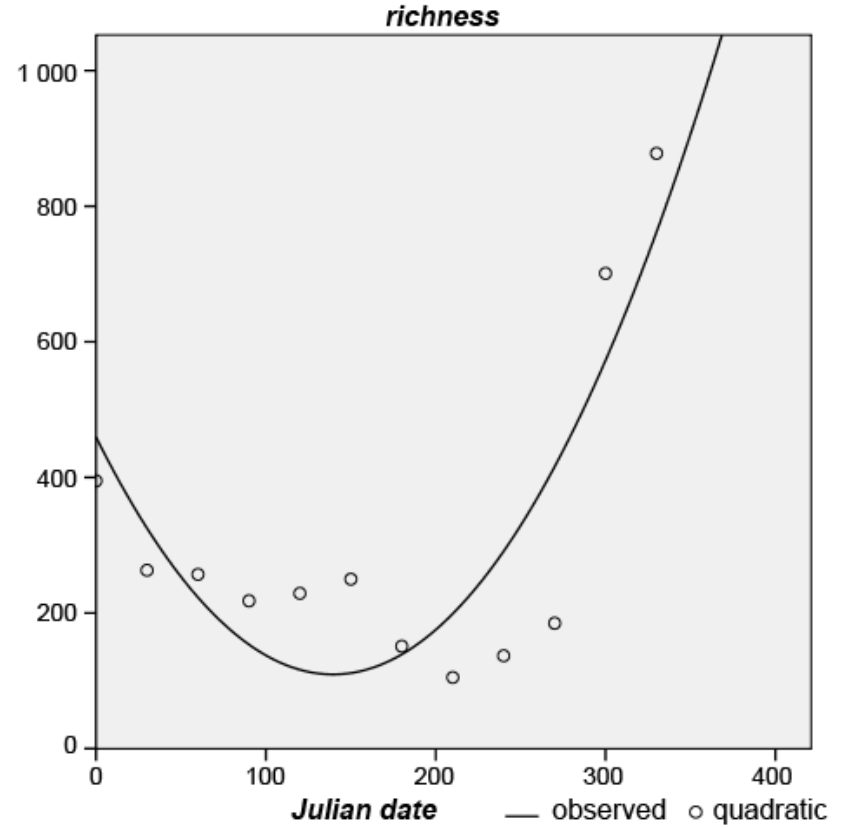

Fig. 2a. Temporal variation of waterbird richness in Mavoor.

Panchayath - Pipe Line, Kalpalli, Palliyol, Mavoor Vayal, and Grasim Lagoon. The present study, we included wetlands from Thengilakadavu to Palliyol $\left(\mathrm{N} 11^{\circ} 15 \$ 73.3^{2}\right.$ and E75 $\left.55 \$ 94.4^{2}\right)$ with an area of 146.01 ha located at 13 m elevation from the sea level. Mavoor wetland consists of three habitat types:

- Agricultural land: Only a small portion of the Mavoor wetland is allotted for cultivation of banana and paddy. Water level up to $0.6 \mathrm{ft}$ is found during monsoon, and common fishes are present due to the connection with the open water body. At the end of monsoon, it dries, and sedges emerge by summer.

- Covered water body: The water bodies have more than $50 \%$ of the area covered with sedges and cattails like Carex and Scirpus sp. This habitat has a thin layer of water with fishes, frogs, grasshoppers, dragon flies, and other insects. Sedges dry up in summer, later emerge in monsoon.

- Open water body: Exposed water body with seasonal variation in the abundance of vegetation like Salvinia and Nymphaea sp. This habitat also includes Pandanus sp. and submerged aquatic plants like Elodea sp. along with aquatic insects, odonates, grasshoppers, frogs and fishes. Salvinia sp. starts growing in monsoon and covers the open water body, it dries up in summer.

Vazhakkad wetland is also situated on the banks of the river Chaliyar $\left(\mathrm{N} 11^{\circ} 14 \$ 66.0^{2}\right.$ and $\left.\mathrm{E} 75^{\circ} 56 \$ 81.2^{2}\right)$, covering an area of approximately 37.0623 ha. Vazhakkad wetland is divided into three subdivisions:

- Agricultural land: More than 50\% of the wetland is waterlogged only during the monsoon and after which a thin layer of water is retained till early summer. Fallow period is from April to October, the cultivation includes paddy (October to April) and banana along with crop rotation. Subsequently the field dries, with the onset of monsoon grasses and other

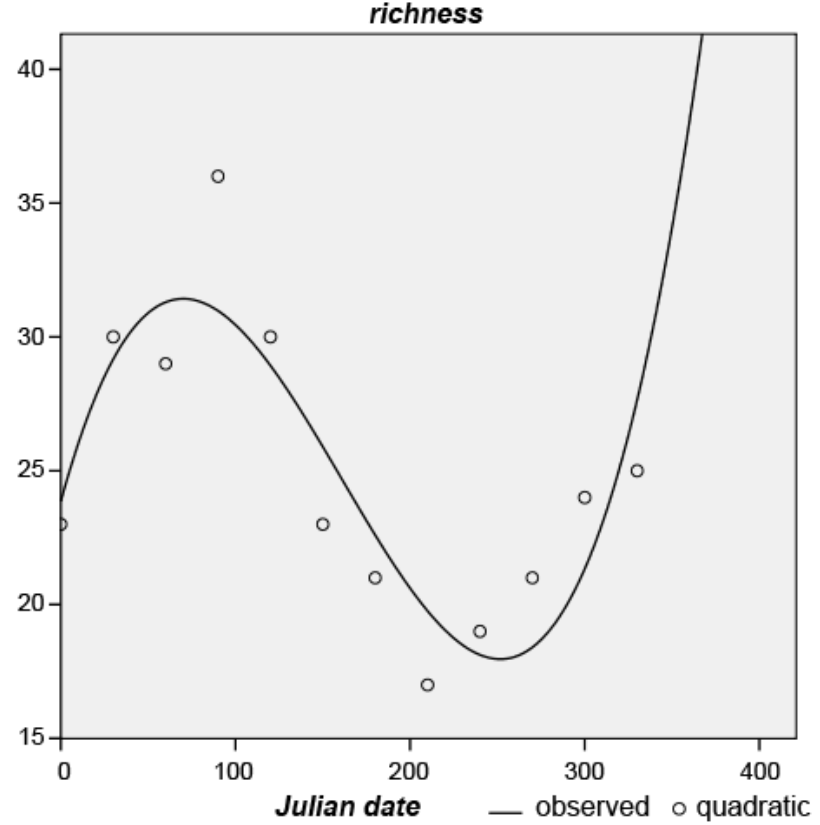

Fig. 2b. Temporal variation of waterbird richness in Vazhakkad.

small plants grow. Agricultural land hosts orthopterans, frogs and fishes in monsoon.

- Covered water body: Water depth is approximately less than $1 \mathrm{~m}$, dominated by small grasses belonging to Poaceae family.

- Open water body: Water depth is approximately $2.5 \mathrm{~m}$, dominated by Salvinia, Nymphaea, and Elodea sp.

\section{Waterbird survey}

The avian surveillance was carried out thrice in a month. Line transect method (Gaston, 1975) was used for the population assessment of waterbirds. In both the study areas, a long transect of $2.5 \mathrm{~km}$ was selected with $50 \mathrm{~m}$ belt on either side of transects (100 $\mathrm{m}$ wide strip). The plot was divided into different sectors, in which each sector was examined for $15 \mathrm{~min}$ and the waterbirds were surveyed from 07:00 to 13:00 $\mathrm{h}$.

The status of waterbirds was categorized into Common (Com; seen on most of the visits), Uncommon (UnCom; seen less than five times) and Rare (Ra; seen once or twice). Migratory status of waterbirds was classified into Resident (R), Local Movement (LM) and Migrant (M). Waterbirds were observed using a binocular $($ NIKON $10 \times 50)$ and identified with the help of field guide (Grimmet et al., 1999). For more accurate identification, video camera (SONY HDR-cX130E) was used to capture photographs and video clips. GPS was used to compute area and distance of the field.

\section{Measurement of hydrological and sediment variables}

Water sample (1 ltr) was taken once in a month from each of the three habitat types in the study area at 12:00 h. Nine physicochemical variables were quantified using the protocol in the American Public Health Association Manual (APHA, 2005). 


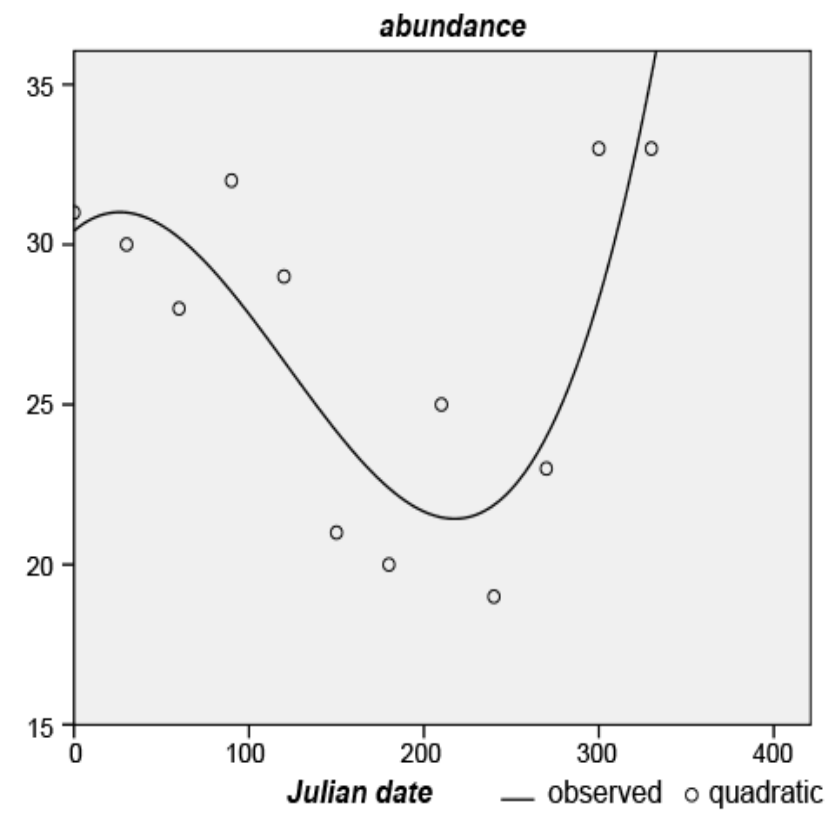

Fig. 3a. Temporal variation of waterbird abundance in Mavoor.

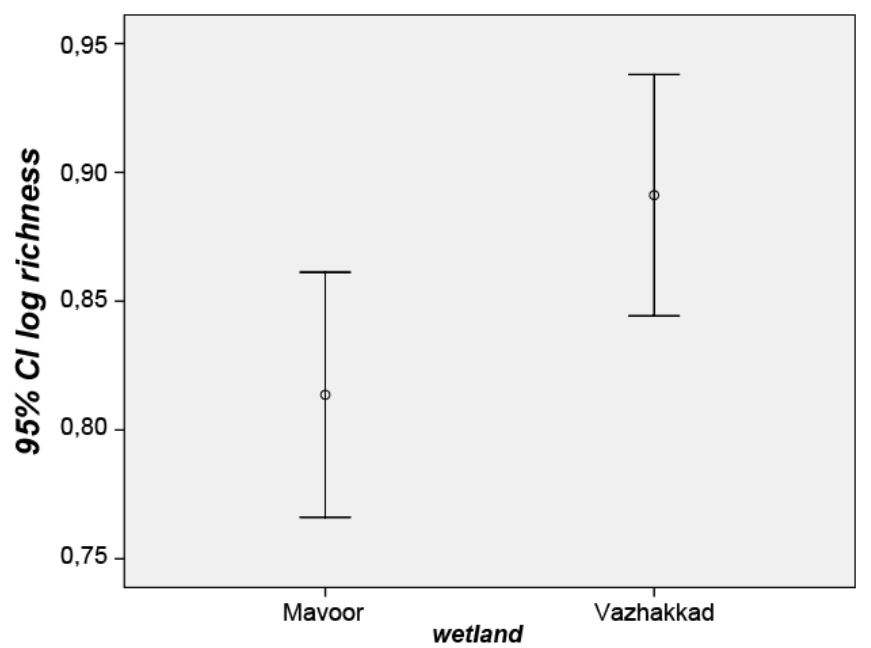

Fig. 4a. Variation in richness between the two wetlands.

Soil samples were collected from the different habitats at 12:00 h. Nine chemical variables were analyzed from Regional Rice Research Institute, Pattambi.

\section{Data analysis}

All variables were tested for homoscedasticity using Levene's test and for normality using a one-sample KolmogorovSmirnov test at a $95 \%$ confidence level. Where possible, nonnormally distributed variables were $\log 10$ transformed to improve the normality of the data. Ecological index was analyzed using MANOVA. It was carried out with abundance, richness, and Shannon Index of waterbird species as dependent variables

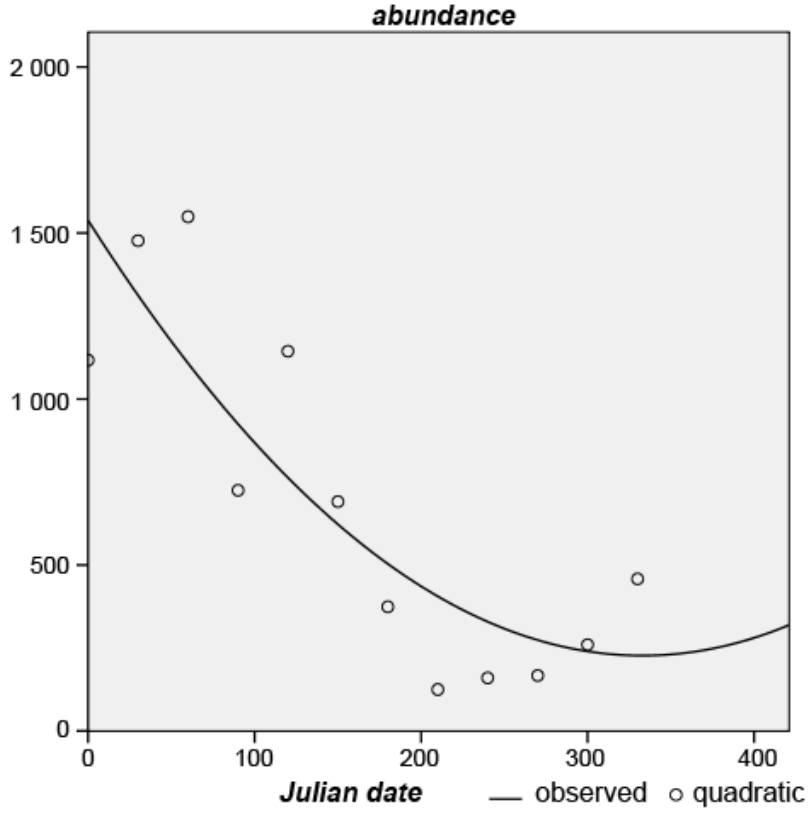

Fig. 3b. Temporal variation of waterbird abundance in Vazhakkad.

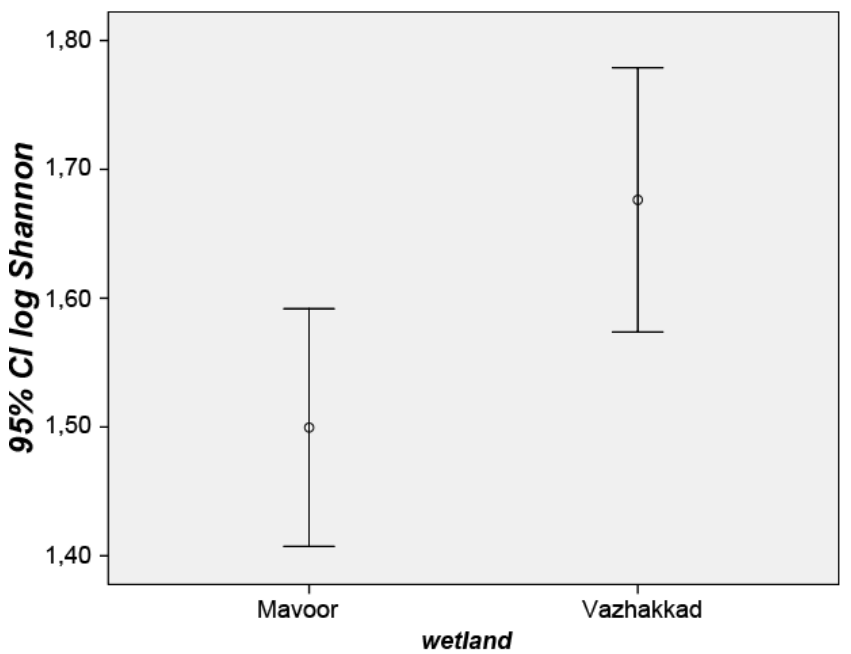

Fig. 4b. Variation in diversity between the two wetlands.

and habitat \& wetland as independent variables (Wilks' lambda was the test criterion). Significant effects were further explored through one-way ANOVA, complemented with LSD tests. Nonlinear regression (quadratic and cubic regression) analyses were done between the evolution of the ecological index in two wetlands separately to find their inter-monthly variation as a function of the progress of the study period in Julian date (December $1=0$ Julian date, first day of monitoring in field until November $30=360$ days with an interval of 30 days). Given that the original sediment and hydrological variables were highly inter-correlated (see the "Results" section), a Principal Components Analysis (Morrison, 1967) was carried out to summarize them into a few independent factors providing 


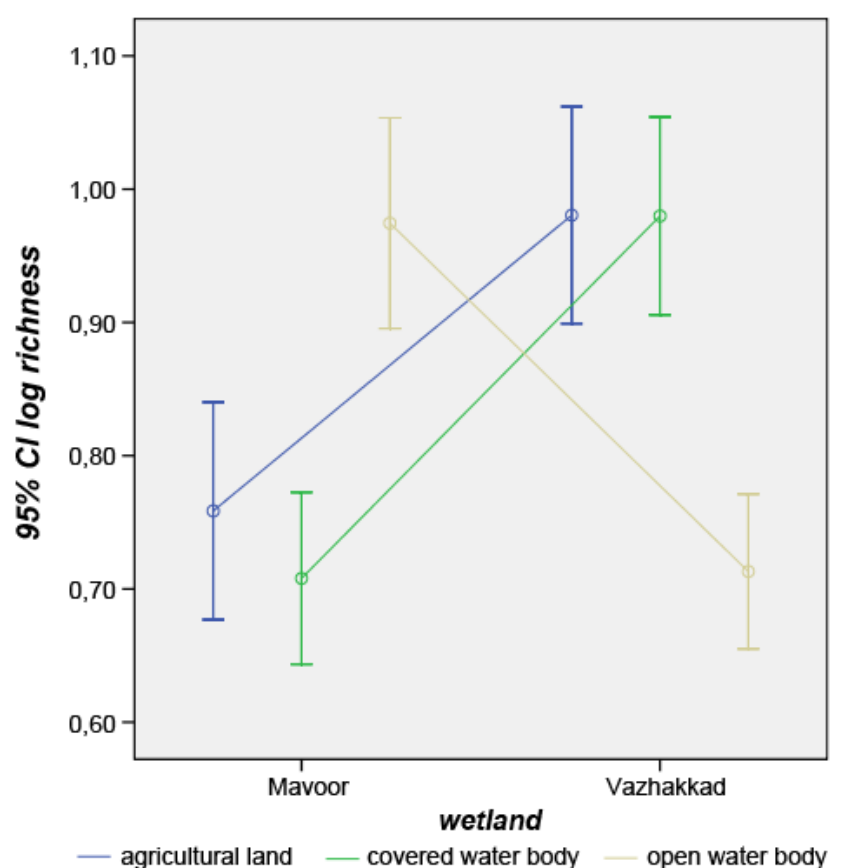

Fig. 5a.Variation in richness between habitats in the two wetlands.

composite measures of site characteristics. This PCA was performed on the average value of each variable in each site, and only the factors whose eigenvalues were greater than 1 were retained (Quinn, Keough, 2002). Finally, Pearson correlation test was used to investigate the relationships between site descriptors derived from the PCA, as explanatory variables and the abundance, richness, and diversity in two wetlands separately. All statistical analyses were carried out using SPSS 17 software.

\section{Results}

\section{Waterbird status and habitat use}

A total of 50 species from Vazhakkad and 40 species from Mavoor wetlands were recorded with greater abundance in February (Mavoor) and November (Vazhakkad); 12 species were exclusive to Vazhakkad and three to Mavoor. Among them, 16 species were winter visitors in Vazhakkad and nine in Mavoor (Table 1).

In Mavoor, waterbird richness showed a variation across months (quadratic regression $R^{2}=0.740, P=0.002$ ) with a decline of richness from December to June and peak in October, whereas in Vazhakkad (cubic regression $R^{2}=0.776, P=0.006$ ), waterbird richness showed a temporal variation (highest richness during the month of March $(S=36)$ ) (Figs 2a, b).

A decrease of waterbird abundance was recorded in Mavoor (cubic regression $R^{2}=0.697, P=0.018$ ) from December till August, and then it showed an increasing trend till November. At Vazhakkad, waterbird abundance decreased with the passage of time (quadratic regression $R^{2}=0.737, P=0.002$ ) (Figs 3a, b).

Ecological index did not vary among the three habitats each of Mavoor and Vazhakkad (MANOVA: Wilks' $\lambda=0.963$, $F=0.985, P=0.447)$, but varied between the two wetlands

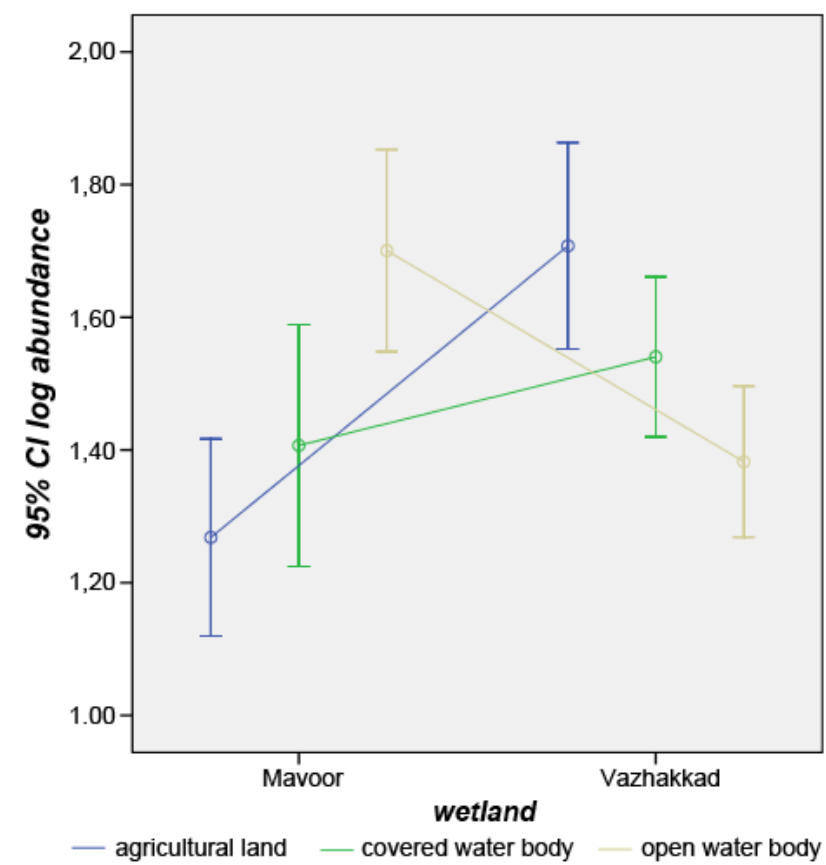

Fig. 5b. Variation in abundance between habitats in the two wetlands.

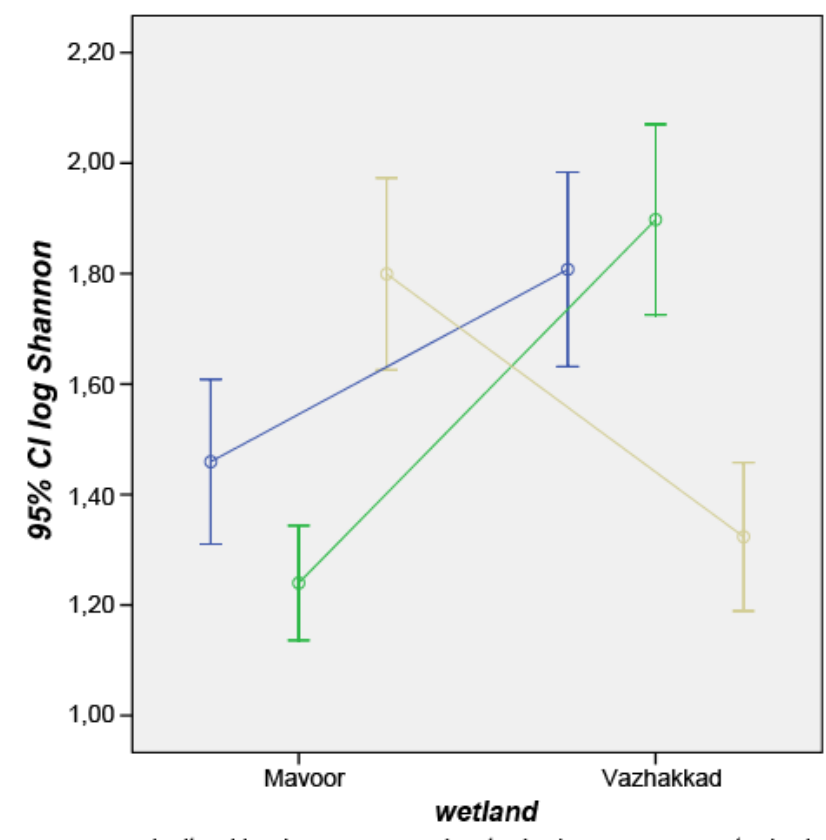

Fig. 5c. Variation in diversity between habitats in the two wetlands.

(MANOVA: Wilks' $\lambda=0.933, F=3.69 P=0.006$ ) and their interaction (MANOVA: Wilks' $\lambda=0.694, F=10.25, P=0.000$ ). The richness did not vary among the three habitats $(F=0.595, P=$ $0.533)$, but varied between the two wetlands $(F=7.46, P=0.007)$ and their interaction $(F=32.31, P=0.000)$ (Figs $4 \mathrm{a}, 5 \mathrm{a})$. The 
Table 2. Rotated component matrix.

\begin{tabular}{|c|c|c|c|c|c|c|}
\hline \multicolumn{7}{|c|}{ Component } \\
\hline & 1 & 2 & 3 & 4 & 5 & 6 \\
\hline Calcium & 0.741 & -0.298 & 0.183 & -0.11 & 0.444 & -0.084 \\
\hline Magnesium (Water) & 0.265 & 0.168 & 0.005 & -0.098 & 0.785 & 0.095 \\
\hline Phosphate (Water) & 0.52 & 0.176 & -0.034 & -0.15 & -0.396 & 0.524 \\
\hline Nitrate & 0.647 & 0.271 & 0.09 & -0.399 & 0.143 & 0.001 \\
\hline Potassium & 0.722 & 0.105 & 0.247 & 0.164 & -0.019 & -0.093 \\
\hline Sulphate (water) & 0.767 & -0.041 & -0.008 & -0.247 & 0.039 & 0.116 \\
\hline $\mathrm{Ph}$ (water) & 0.277 & -0.158 & 0.291 & -0.741 & 0.006 & 0.136 \\
\hline Water temperate & -0.196 & -0.086 & -0.8 & 0.249 & -0.138 & -0.041 \\
\hline Air temperate & -0.184 & -0.052 & -0.9 & 0.041 & 0.115 & 0.074 \\
\hline Humidity & 0.164 & -0.177 & 0.557 & 0.651 & -0.132 & -0.013 \\
\hline Salinity (Water) & -0.128 & -0.125 & -0.032 & 0.757 & -0.172 & 0.115 \\
\hline Calcium (Soil) & -0.128 & -0.123 & -0.053 & -0.185 & 0.258 & 0.848 \\
\hline Magnesium (Soil) & 0.15 & 0.161 & 0.173 & 0.373 & 0.143 & 0.831 \\
\hline nitrogen & -0.079 & 0.89 & 0.281 & 0.17 & 0.114 & 0.13 \\
\hline Potassium (Soil) & -0.095 & 0.208 & -0.154 & -0.253 & 0.736 & 0.291 \\
\hline Iron (Soil) & -0.219 & 0.52 & 0.667 & 0.166 & -0.097 & 0.315 \\
\hline Phosporus & 0.485 & -0.254 & 0.428 & 0.202 & 0.491 & 0.053 \\
\hline $\mathrm{Ph}$ (Soil) & -0.201 & -0.759 & -0.08 & 0.402 & 0.181 & 0.318 \\
\hline Salinity (Soil) & 0.071 & 0.827 & -0.155 & -0.145 & 0.355 & 0.073 \\
\hline
\end{tabular}

Table 3. Correlation of waterbird abundance, richness, diversity, and equitability to six axes in Mavoor and Vazhakkad.

\begin{tabular}{|c|l|c|c|c|c|c|c|}
\hline Wetland & Ecological index & Axis 1 & Axis 2 & Axis 3 & Axis 4 & Axis 5 & Axis 6 \\
\hline \multirow{3}{*}{ Mavoor } & Abundance & 0.233 & $0.608^{*}$ & 0.276 & 0.521 & -0.087 & -0.501 \\
\cline { 2 - 9 } & Richness & 0.271 & -0.039 & 0.105 & $0.788^{* *}$ & -0.478 & -0.013 \\
\cline { 2 - 9 } & Diversity & -0.354 & 0.199 & $0.625^{*}$ & 0.188 & -0.302 & -0.004 \\
\hline \multirow{3}{*}{ Vazhakkad } & Abundance & 0.488 & 0.198 & $0.677^{*}$ & -0.389 & 0.399 & $0.801^{* *}$ \\
\cline { 2 - 9 } & Richness & 0.018 & 0.152 & 0.29 & -0.223 & 0.228 & 0.511 \\
\cline { 2 - 9 } & Diversity & -0.348 & -0.735 & 0.477 & 0.171 & $0.618^{*}$ & -0.48 \\
\hline
\end{tabular}

Notes: ${ }^{\star} 0.05 \%$ level of significance; ${ }^{* \star} 0.01 \%$ level of significance.

abundance did not vary among the three habitats $(F=0.71, P=$ $0.493)$ and the two wetlands $(F=2.0 .86, P=0.150)$, but varied in their interaction $(F=12.11, P=0.000)$ (Fig. 5b). Shannon index did not vary among the three habitats $(F=0.812, P=0.446)$, but varied between the two wetlands $(F=8.70, P=0.004)$ (Fig. $4 \mathrm{~b})$ and their interaction $(F=29.5, P=0.000)$ (Fig. 5c).

Waterbird diversity in Mavoor was lowest in agricultural land during December to March and showed an increasing trend from April whereas in the open water body, there was a drastic drop in diversity during summer (March to May). Vazhakkad agroecosystem recorded lesser diversity during summer and showed an increase with the onset of June, but covered water body had its peak diversity in summer and declined from June onwards; open water body with almost a stable diversity.

\section{Substrate quality and waterbirds}

Loading plots of principle components 1-6 of the PCA results obtained from water and sediment quality are illustrated in
Table 2. In this study, the PCA explained $91.34 \%$ of the total variance. The first component (Axis 1) represented calcium, phosphate, nitrate, potassium, sulphate (water); the second component (Axis 2) represented nitrogen, $\mathrm{pH}$, salinity (soil); the third component (Axis 3) represented iron (soil), water temperature, air temperature; the fourth component (Axis 4) represented $\mathrm{pH}$, salinity (water), humidity; the fifth component (Axis 5) represented magnesium (water), potassium (soil) and the sixth component (Axis 6) represented calcium, magnesium (soil), phosphate (water).

Physicochemical variables were estimated for the two wetlands, and their effects on waterbird richness, abundance, diversity and equitability were correlated. From the analysis of correspondence, waterbird abundance was positively correlated to Axis $2(r=0.608, P=0.036)$, waterbird richness to Axis $4(r=0.788, P=0.002)$ and waterbird diversity to Axis $3(r=$ $0.625, P=0.030)$ in Mavoor. Whereas in Vazhakkad, waterbird abundance was positively correlated to Axis $3(r=0.677, P=$ 0.016 ) and waterbird diversity positively correlated to Axis 5 
$(r=0.618, P=0.032)$ and negatively correlated to Axis $2(r=$ $-0.735, P=0.006$ ) (Table 3).

\section{Discussion}

Habitat variables such as water quality and sediment parameters affect the distribution of waterbirds in a particular wetland (Nagarajan, Thiyagesan, 1996), which act as a criterion in evaluating the quality of the wetlands. In the present study, waterbird richness and diversity were higher in Vazhakkad compared to Mavoor wetlands. These wetlands also act as an alternate habitat for the waterbirds during the post-monsoon season.

Certain waterbird populations that show declining trends (BirdLife International, 2016) were recorded from the wetlands- Black Capped Kingfisher Halcyon pileata from Mavoor; Grey Plover Pluvialis squatarola, Pacific Golden Plover P. fulva, Ruddy Breasted Crake Porzana fusca, Common Snipe Gallinago gallinago, River Tern Sterna aurantia from Vazhakkad wetlands. Waterbirds effectively used different habitats based on their requirements in different seasons. In Mavoor, the waterbird diversity was found higher in open water body whereas in Vazhakkad, highest diversity was observed in covered water body and agricultural lands. Similarly, abundance and richness were found to be higher in open water body in Mavoor and agricultural lands in Vazhakkad. This has been supported by the studies by Elphick and Oring (2003) wherein they described agricultural lands as the productive and biologically rich areas of the world. Studies by Czech and Parsons (2002) also put forth the importance of rice fields as a primary foraging ground for waterbirds.

The diversity, abundance, and richness pattern of waterbirds vary across months. This indicates the alteration in quality of wetlands due to the change in climatic and physicochemical parameters. This suggests the importance of prey and other benthic organisms in determining the diversity and abundance of waterbirds in a wetland (Pandiyan et al., 2014). Present study showed a sharp decline in waterbird richness in Mavoor wetlands compared to the previous observations by Aarif and Basheer (2012), which evoke the possibility of anthropogenic disturbance affecting waterbird richness in wetlands.

In the present study, calcium, magnesium, nitrogen, $\mathrm{pH}$, iron, phosphate, and salinity were correlated to waterbird abundance. Higher calcium level causes increased hardness of water (Bhat et al., 2009). It inhibits clay dispersion and disruption of aggregates, which increases the water-leaching capacity of soil (Wuddivira, 2007). This in association with $\mathrm{pH}$ (Brady and Weil, 2002) may cause prey abundance (Balapure et al., 2013), thereby increasing the number of waterbirds. Studies by Patterson (1976) proved brood density of ducks to be higher in hard water ponds which is in agreement with our study. Long term studies need to be carried out for establishing the relationship of waterbird assemblage with sediment and hydrological parameters. Increase in calcium at Vazhakkad may be due to the excessive application of fertilizers in the agroecosystem however, no correlation with calcium was observed at Mavoor.

In this study, nitrogen in the sediment showed a negative correlation with waterbird diversity in Vazhakkad wetlands, whereas no effect in Mavoor wetlands. The limiting effect of nitrogen enhances prey distribution and abundance (Nagarajan, Thiyagesan, 1996; Aarif et al., 2014) which indicate the negative correlation of nitrate with waterbirds.

Availability of micro-invertebrates and limnology highly depend on the structure of macrophyte communities and habitat morphometry (Lillie, Evrard, 1994). Reduction in species richness of phytoplankton and macrophytes was observed following nutrient addition (Nilsson and Nilsson, 1978), which is evident in the current study where a sharp increase in phosphorus in the month of May-due to agricultural runoff-lead to the decrease in waterbird diversity at Mavoor wetlands. Excessive application of fertilizers in the agroecosystem or waste deposition may result in the accumulation of unfit conditions in the wetlands for the top-level avian predators like kingfishers (Renila et al., 2020) and other waterbirds.

In the current study, a positive correlation of waterbird abundance and richness with salinity was noted, which suggest these wetlands as an important wintering/roosting area. Since the salinity of wetlands is always less than $0.8 \mathrm{ppt}$, both the sites are freshwater wetlands and provide a healthy habitat for invertebrate growth, and thereby waterbirds. Salinity acts as a primary factor that determines the diversity of aquatic organisms (Manikannan et al., 2012) and macrobenthic assemblages, which in turn affect the population of waterbirds (Sumathi et al., 2008). Climatic factors also have a significant effect on the distribution of waterbirds (Rajpar and Zakaria, 2011). Low water and air temperature lead to an increase in waterbird richness (Balapure et al., 2013). This is consistent with the present study, where an increase in temperature during the months from March to May resulted in decrease in waterbird species richness.

Manufactured sand unit on the banks of Mavoor wetland also lowered the water infiltration capacity of the wetlands. Manufactured sand is an alternative for the mining of river sand (Joe et al., 2013; Jadhav et al., 2013), but when a manufactured sand unit is located near to a wetland, the washed sand particles of less particle size are sent to the wetland and they lead to loss of infiltration capacity of the wetland. Deposition of waste from households, poultry farms and slaughter houses in plastic carry bags along with a rapid increase in human settlement are the major anthropogenic stresses noticed in both wetlands during the study period. Runoff from agricultural lands can lead to nutrient enrichment in the waterbody and can affect waterbird abundance through changes in benthic invertebrates (Blann, 2009). Chemicals applied to the field include Factomphos, Roundup, and Furadan which impact the wetland quality. Waste dumping (Wilcox et al., 2015) especially accumulation of plastic waste (Sandilyan, Kathiresan, 2012) poses a serious threat to wetland ecosystems and marine life, including shorebird populations.

Developing effective measures for the conservation of waterbirds in Mavoor and Vazhakkad wetlands depends critically on understanding their current status, the effects of environmental change and the impacts of anthropogenic pressures. Improving awareness about lessening disturbances to the wetlands in the local communities is essential for the sustainable management of these wetlands. Since Vazhakkad wetlands also hosts wintering waterbirds, usage of appropriate volume of pesticides and proper awareness creation 
among the local people by the higher authorities are essential. Although the present study might be considered as a fundamental step towards the protection of waterbirds in Mavoor and Vazhakkad wetlands, long-term monitoring is critically required for the conservation and management of these important wetlands.

\section{Acknowledgements}

Authors are thankful to Dr. M. Nasser, Department of Zoology, Calicut University, for the helpful suggestions that improved the manuscript. We are indebted to CWRDM and RRI for the timely analysis of water and sediment samples. We are thankful to the local people of Mavoor and Vazhakkad who helped during field visits. The editor and reviewer each made useful comments that improved this manuscript.

\section{References}

Aarif, K.M. \& Basheer M. (2012). The waterbirds of Mavoor Wetland, Kerala, South India. World Journal of Zoology, 7(2), 98-101. DOI: 10.5829/idosi.wjz.2012.7.2.6216

Aarif, K.M., Muzaffar, S.B., Babu, S. \& Prasadan P.K. (2014). Shorebird assemblages respond to anthropogenic stress by altering habitat use in a wetland in India. Biodiversity Conservation, 23, 727-740. DOI 10.1007/s10531-014-0630-9.

Aarif, K.M., Kaiser, S.A., Nefla, A. \& Almaroofi S. (2020). Over-summering abundance, species composition, and habitat use patterns at a globally important site for migratory shorebirds. The Wilson Journal of Ornithology, 132(1). DOI: 10.1676/1559-4491.

Acosta, M., Mugica, L., Blanco, D., Lopez-Lanus, B., Dias, A.R. Doodnath, L.W. \& Hurtado J. (2010). Birds of rice fields in the Americas. Waterbirds, 33(Suppl.), 105-122. DOI: 10.1675/063.033. s108.

Amezaga, J.M., Santamaria, L. \& Green A.J. (2002). Biotic wetland connectivity-supporting a new approach for wetland policy. Acto Oecologica, 23, 213-222. DOI: 10.1016/S1146-609X(02)01152-9.

APHA (2005). Standard methods for the examination of water and waste water. Washington: American Public Health Association.

Balapure, S., Dutta, S. \& Vyas V. (2013). Physico-chemical factors affecting the distribution of wetland birds of Barna Reservoir in Narmada Basin, Central India. International Journal of Biodiversity and Conservation, 5(12), 817-825. DOI: 10.5897/IJBC12.136.

Bassi, N., Kumar, M.D., Sharma, A. \& Pardha-Saradhi P. (2014). Status of wetlands in India: a review of extend ecosystem benefits, threats and management strategies. Journal of Hydrology: Regional Studies, 2, 1-19. DOI: 10.1016/j.ejrh.2014.07.001.

Bhat, M.M., Yazdani, T., Narain, K., Yunus, M. \& Shukla R.N. (2009). Water quality status of some urban ponds of Lucknow, Uttar Pradesh. Journal of Wetlands Ecology, 2(1-2), 67-73. DOI: 10.3126/ jowe.v2i1.1866.

BirdLife International (2008). Threatened birds of the world. CD-ROM. Cambridge: BirdLife International.

BirdLife International (2016). The IUCN Red List of Threatened Species 2016. http://www.iucnredlist.org

BirdLife International (2017). Waterbirds are showing widespread declines, particularly in Asia. http://www.birdlife.org on 17/09/2020

Blann, K.L., Anderson, J.L., Sands, G.R. \& Vondracek B. (2009). Effects of agricultural drainage on aquatic ecosystems: A review. Critical Reviews in Environmental Science and Technology, 39, 909-1001. DOI: $10.1080 / 10643380801977966$.

Brady, N.C. \& Weil R.R. (2002). The nature and properties of soils. New Jersey: Prentice Hall Inc.

Central Pollution Control Board (CPCB) (2008). Status of water quality in India 2007. New Delhi: Central Pollution Control Board Ministry of Environment and Forests, Government of India.

Czech, H.A. \& Parsons C. (2002). Agricultural wetlands and waterbirds: a review. Waterbirds, 25(Special 2), 56-65. https://www.jstor.org/ stable/1522452
Elafri, A., Belhamra, M. \& Houhamdi M. (2017). Comparing habitat preferences of a set of waterbird species wintering in the coastal wetlands of North Africa: implication for management, Ekológia (Bratislava), 36(2), 158-171. DOI: 10.1515/eko-2017-0014.

Elphick, C.S. \& Oring L.W. (2003). Conservation implications of flooding rice fields on winter waterbird communities. Agricultural Ecosystem Environment, 94(1), 17-29. DOI: 10.1016/S0167-8809(02)00022-1.

Gaston, A.J. (1975). Methods for estimating bird population. Journal of Bombay Natural History Society, 72(2), 271-283.

Grimmet, R., Inskipp, C. \& Inskip T. (1999). Pocket guide to the birds of Indian subcontinent. New Delhi: Oxford University Press.

Hamza, F. \& Selmi S. (2015). Habitat features and human presence as predictors of the abundance of shorebirds and wading birds wintering in the Gulf of Gabes, Tunisia. The Marine Ecology Progress Series, 540, 251-258. https://www.jstor.org/stable/24896655

Jadhav, A., Priyanka, K. \& Dilip K. (2013). Effect of replacement of natural sand by manufactured sand on the properties of cement mortar. International Journal of Civil and Structural Engineering, 3(3), 621-628. DOI: 10.6088/ijcser.201203013057.

Joe, M.A., Rajesh, A.M., Brightson, P. Prem Anand M. (2013). Experimental investigations on the effect of $\mathrm{M}$-sand in high performance concrete. American Journal of Engineering Research, 2(12), 46-51.

Jones, K., Lanthier, Y., van der Voet, P., Valkengoed, E., Taylor, D. \& Fern' andez-Prieto D. (2009). Monitoring and assessment of wetlands using Earth Observation: the GlobWetland project. Journal of Environmental Management, 90(7), 2154-2169. DOI: 10.1016/j.jenvman.2007.07.037.

Lillie, R.A. \& Evrard J.O. (1994). Influence of macroinvertebrates and macrophytes on waterfowl utilization of wetlands in the Prairie Pothole Region of northwestern Wisconsin. Hydrobiologia, 279, 235246. DOI: $10.1007 /$ BF00027857.

Liang, S.H., Sheih, B.S. \& Fu Y.S. (2002). A structural equation model for physico-chemical variables of water, benthic invertebrates and feeding activity of waterbirds in the Sitsao wetlands of Southern Taiwan. Zoological Studies, 41(4), 441-451.

Malik, D.S. \& Joshi N. (2013). Habitat selection pattern of migratory avifauna in relation to nutrients in Asan wetland at Doon valley (Garhwal Himalaya), India. International Journal of Recent Scientific Research, 4(10), 1470-1475.

Manikannan, R., Ashokan, S. \& Ali A.M.S. (2012). Abundance and factors affecting population characteristics of Waders (Charadriiformes) in Great Vedaranyam Swamp of Point Calimere Wildlife Santuary, South- East coast of India. International Journal of Ecosystem, 2(1) 6-14. DOI: 10.5923/j.ije.20120201.02.

Morrison, F. (1967). Multivariate statistical methods. New York: McGrawHill.

Nagarajan, R. \& Thiyagesan K. (1996). Waterbirds and substrate quality of Pichavaram wetlands, Southern India. Ibis, 138(4), 710-721. DOI: 10.1111/j.1474-919X.1996.tb04773.x.

Nilsson, S.G. \& Nilsson I.N. (1978). Breeding bird community densities and species richness in lakes. Oikos, 31, 214-221.

Pandiyan, J., Naresh, B. \& Nagarajan R. (2014). Temporal variations of shorebirds and benthic community, traditional saltpans of east coast of southern India. International Journal of Pure and Applied Zoology, 2(1), 14-25. http://www.ijpaz.com

Patterson, J.H. (1976). The role of environmental heterogeneity in the regulation of duck populations. Journal of Wildlife Management, 40(1), 22-32

Quinn, G.P. \& Keough M.J. (2002). Experimental design and data analysis for biologists. Cambridge: Cambridge University Press.

Rajpar, M.N. \& Zakaria M. (2011). Bird species abundance and their correlationship with microclimate and habitat variables at natural wetland reserve, Peninsular Malaysia. International Journal of Zoology, 758573. DOI: $10.1155 / 2011 / 758573$.

Renila, R., Bobika, V.K., Aymen N., Manjusha, K. \& Aarif K.M. (2020) Hunting behavior and feeding success of three sympatric kingfishers' species in two adjacent wetlands in Southwestern India. Proceedings of the Zoological Society, 73(3). DOI: 10.1007/s12595-020-00344-4.

Sandilyan, S., Thiyagesan, K. \& Nagarajan R. (2010). Major decline in species-richness of waterbirds in the Pichavaram mangrove wetlands, southern India. Wader Study Group Bulletin, 117(2), 91-98. 
Sandilyan, S. \& Kathiresan K. (2012). Mangrove conservation: a global perspective. Biodiversity Conservation, 21(14), 3523-3542. DOI: 10.1007/s10531-012-0388-x.

Shine, C. \& Klemm C. (1999). Wetlands, water and law: using law to advance wetland conservation and wise use. Gland: IUCN.

Stroud, D.A., Davison, N.C., West, R., Scott, D.A., Haanstra, L., Thorup, O., Ganter, B. \& Delany S. (2004). Status of migratory wader populations in Africa and Western Eurasia in the 1990s. International Wader Studies, 15, 1-259.

Strum, K.M., Reiter, M.E., Hartman, C.A., Iglecia, M.N., Kelsey, T.R. \& Hickey C.M. (2013). Winter management of California's ricefields to maximize waterbird habitat and minimize water use. Agricultural Ecosystem Environment, 179, 116-124. DOI: 10.1016/j.agee.2013.08.003.

Sumathi, T., Nagarajan, R. \& Thiyagesan K. (2008). Effect of water depth and salinity on the population of Greater Flamingo (Phoenicopterus ruber) in Point Calimere Wildlife Sanctuary, Tamil Nadu, Southern India. Scientific Transactions in Environment Technovation, 2(1), 9-17.

Sundar, K.S.G. \& Subramanya S.S. (2010). Bird use of rice fields in the Indian subcontinent. Waterbirds, 33(Suppl.), 44-70. DOI 10.1675/063.033.s104.
Wetlands International (2012). Waterbird population estimates. Wageningen: Wetlands International.

Wilcox, C., Van Sebille, E. \& Hardesty B.D. (2015). Threat of plastic pollution to seabirds is global, pervasive, an increasing. Proceedings of National Academy of Sciences of USA, 112(38), 11899-118904. DOI: 10.1073/pnas.1502108112.

Wuddivira, M.N. \& Camps-Roach G. (2007) Effects of organic matter and calcium on soil structural stability. European Journal of Soil Sciences, 58, 722-727. DOI: 10.1111/j.1365-2389.2006.00861.x.

Zeenath, C. (2009). Behaviour and adaptations of little Cormorant (Phalacrocorax niger) and Darter (Anhinga melanogaster). Ph.D thesis, University of Calicut, Kerala.

Zheng, M., Zhou, L.Z., Zhao, N.N. \& Xu W.B. (2015). Effects of variation in food resources on foraging habitat use by wintering hooded cranes (Grus monacha) in Shengjin Lake, China. Waterbirds, 33(1), 110-115. DOI:10.1675/063.033.0114. 